\title{
Islamic Education in Singapore: Case Study Madrasah Al-Juneid Al-Islamiyah
}

\author{
${ }^{1}$ Naimah Radzi, ${ }^{2}$ Avid Leonardo Sari, ${ }^{3}$ Irwandi \\ ${ }^{1}$ Centre for International Islamic Culture, Malaysia \\ ${ }^{23}$ Center for Asian Social Science Research, Indonesia \\ Email: naimah.r@gmail.com
}

\begin{abstract}
This article explains the development of Islamic education in Singapore, specifically Madrasah al-Juneid al-Islamiyah. The problem: how is curriculum development at Madrasah al-Juneid? And what are the challenges of the future of this madrasa? To answer this problem, the amount of data collected through the method of observation, interviews, and documentation. Data collected were analyzed descriptively-qualitatively. The results show: first, the curriculum at Madrasah al-Juneid initially did not contain pure religion then was expanded by adding general lessons. In learning, study materials are commonly used to approach integration with Islamic teachings. Second, madrassas in Singapore face challenges in the future that are not easy, namely the demands of the world of work, demands for quality, challenges of Western lifestyles, and accusations against Islam as a terrorist religion. Creative madrassas must address all these challenges in developing quality programs so that graduates can compete with graduate schools, can fortify modern secular lifestyles, and can coexist peacefully during Singapore's diverse society.
\end{abstract}

Keywords: Islamic Education, Madrasa, Curriculum, Madrasa Al-Juneid.

\section{A. INTRODUCTION}

Islamic education can mean a process or an institution. As a process, Islamic education is a conscious and planned effort to develop the potential of students toward the formation of a perfect Muslim person through efforts to direct, teach, train, set an example, guide, nurture, and supervise Islam. Whereas, as an institution, Islamic education is an educational institution whose establishment and implementation are based on Islamic values and to realize Islamic ideals. The existence of Islamic education institutions in a country is quite diverse in types, and its level depends on the traditions of the local Islamic community and the policies of the government in a country. In Indonesia, Islamic education institutions can be found from the level of basic education to tertiary education with diverse types and amount to thousands.1 Whereas in Singapore, Islamic educational institutions are only limited to primary and secondary 
education levels with a limited type and amount. In this lion country, there are two types of Islamic educational institutions, namely full-time madrassas, and part-time madrasas.

Full-time madrassas are Islamic educational institutions whose learning processes take place every day as is the case with madrasas in Indonesia, and the curriculum combines religious and general subjects. Whereas a half-time madrasa is an educational institution whose learning process does not take place every day, maybe two or three times a week, held in the afternoon and evening, the material is purely religious, and generally takes place in mosques. With this character, half-time madrasas are more accurately called non-formal education.

Both types of madrasa have different arable fields. The target of the full-time madrasa is Muslim students who, from the beginning, chose this institution as a place to develop their potential. Whereas part-time madrasas target Muslim students, who study in public schools, so that they are familiar with the basic teachings of Islam, considering that public schools in Singapore do not teach religious subjects. 4 Thus, both types of madrasas share a significant role in nurture an Islamic spirit early on for generations of Muslims.

Of the types of madrasas that are now developing in Singapore, the study in this paper is focused on full-time madrasas (especially full-time), especially Madrasas alJuneid al-Islamiah. This madrasa was chosen because it has advantages over other madrassas in Singapore. The proof, this madrasa visited by many Islamic education providers outside Singapore in the context of comparative studies; This madrasa attracts many Muslim parents and students in Singapore, Malaysia, and Brunei Darussalam; many al-Juneid alumni who continue/are accepted at leading Islamic universities in the world, especially al-Azhar University of Egypt; and many of these madrasa graduates have become religious leaders in Singapore, Malaysia, and Brunei Darussalam. The study of Madrasah al-Juneid focused on the following problems; how is the curriculum developed at Madrasah al-Juneid?; and what are the challenges facing this madrasa? To answer this problem, several related data were collected through methods of observation, interviews, and documentation. The data collected was analyzed descriptively-qualitatively.

\section{B. RESULT AND DISCUSSION}

\section{Islamic People In Singapore}

Singapore is a small country in Southeast Asia located in the Malay Peninsula, bordering Johor (Malaysia) and Riau Islands (Indonesia). This country became independent on August 9, 1965, after a long period of British colonization (1819-1963). Singapore was originally a fishing village inhabited by ethnic Malays. After independence, the standard of living in this country increased sharply. The country is 
the fourth leading financial center in the world and a cosmopolitan world city that plays a vital role in international trade and finance. The Port of Singapore is one of the five busiest ports in the world. Singapore is said to be the most globalized country in the world in the 2006 Globalization Index. The Economist Intelligence Unit ranks Singapore as the first best quality of life in Asia and the eleventh in the world. This city-state has the ninth-largest foreign exchange reserves in the world. This country also has superior armed forces. Singapore's economic growth is the fastest in the world with GDP (Gross Domestic Product) growth of $17.9 \%$ in the first half of 2010.

The total area of Singapore is currently around $7.10 \mathrm{~km} 2$ (271.8 miles). While the population, based on the 2010 population census, reached 5.8 million people consisting of ethnic Chinese (77.3\%), ethnic Malays (14.1\%), Indians (7.3\%), and other ethnicities $(1.3 \%)$. Ethnicity is a native of Singapore which is increasingly marginalized.

The majority of Singaporeans are Buddhists (32.08\%), the rest are Christians $(17.68 \%)$, Islam (14.21\%), Taoists (10.53\%), Hindus $(4.90 \%)$ and followers other religion $(0.67 \%)$. While the rest $(16.38 \%)$ has no faith. The majority of Muslims are ethnic Malays. The rest are from the Indian and Pakistani communities and a small number from China, Arabia, and Eurasia. The majority of Singapore's Muslim population has traditionally been Sunni Muslims who follow the Shafi'i school, and there are also Muslim followers of the Hanafi school of thought and a few Shia Muslims. In line with population growth, the number of Muslims in Singapore is increasing every time. The same thing also happened to followers of other religions, including those who had no faith, except Taoism, which experienced a significant decline. This can be seen in the statistical table of population-based on religion for the period 1980-2010:

The entry of Islam into Singapore cannot be separated from the process of the entry of Islam into Southeast Asia in general, because geographically Singapore is one of the small islands found in the Malay Peninsula land. In the early days, Islam, which was introduced to the people of Southeast Asia, was more thick with the nuances of Sufism. Therefore, the spread of Islam in Singapore is inseparable from this style of Sufism. The proof of the teaching of Sufism turned out to be very popular with local scholars and Malay kings. The most extensive collection of Sufi orders in Singapore, which still exists today, is the Tariqah 'Alawiyyah found in the Ba'alawi Mosque. This order is led by Sayid Hasan bin Muhammad bin Salim al-Attas. To deal with matters relating to Muslims in Singapore, the lion country government established the Majlis Ulama Islam Islam (MUIS) or Islamic Religious Council of Singapore in 1968. The authority of this state-owned official body includes the fostering and development and supervision of mosques, Islamic education, marriage, zakat, hajj, sacrifice, halal certification, fatwa, and other related matters. The state finances MUIS activities. Even its officials and employees, including the country's mufti, are appointed by the nonMuslim Singaporean President. 
Judging from the number of minority Muslims and the existence of a secular Singapore state, the establishment of MUIS by the country is a form of more concern from the Singapore government towards Muslims, given that similar institutions do not exist for other religions, even though their adherents are higher than Islam. But from a political aspect, the establishment of MUIS can be seen as a tactical step by the Singapore government to control Muslims from within. Not surprisingly, some Singaporean Muslim activists view the existence of MUIS as explainers of government policies, "explainers of government policy." This term emerged, among other things, following a debate over the banning of the headscarf by the government in public schools in 2002. At that time, two Muslim girls were banned from school for refusing to remove the hijab during study hours. The government argues, the ban on veils in public schools aims to create a harmonious atmosphere between religions and ethnicities in the school environment. MUIS supports government policy by saying, "The prohibition on hoods only lasts a few hours when students are in school. Education is more important. "

As an arm of the government, MUIS also conducts oversight of Friday sermons in each mosque to ensure the contents of the discourse following the concept of a pluralistic state of Singapore. Lecturers who come from outside are also required to arrange a lecture permit to MUIS before they can speak in Singapore. However, apart from the pros and cons of MUIS, this institution has done a lot for the progress of Muslims in Singapore, including in the development of Islamic education.

\section{Madrasah in Singapore}

Although the phenomenon of madrasas in the Islamic world has emerged around the 4 th/5th H (10/11 AD), such as the emergence of madrassas in NaisaphurIran $( \pm 400$ $\mathrm{H})$ and Madrasa Nidzamiyah in Baghdad $(457 \mathrm{H}), 16$ the existence of madrasas in Singapore only found in the early 20th century. The first madrasa was Madrasah alSibyan. This madrasa was founded in 1905 with the main focus of education (memorization) of the Koran. Whereas the first modern madrasa was established as Madrasah al-Iqbal. This institution was founded in 1908 by Islamic reformers in this country. The modernization of Madrasah al-Iqbal appears in the curriculum, which in addition to Islamic studies, also offers general subjects such as geography, history, mathematics, and even English. However, due to the lack of positive response from the Singapore Muslim community at the time, the madrasa was closed a year later. If linked to the modernization of madrassas in Indonesia, the movement carried out by Muslim reformers in Singapore is almost the same time as that which occurred in Indonesia. In the largest Muslim country in the world, Muslim reformers also modernized madrasa in the early 20th century, precisely in 1909, which was marked by the establishment of Adabiyah Madrasah in Padang Panjang.17 Some writers of Islamic education history 
mention two critical events that are underlying the emergence of the modernization movement madrasa in the Islamic world, namely colonialism and Islamic renewal movements that echoed from the Middle East.

Some historians of Islamic education such as Munir al-Din Ahmed, George Makdisi, Ahmad Syalabi, and Michael Stanton argue that the first madrasa emerged was the Nidzamiyah Madrasa founded by Wazir Nidzam al-Mulk around 457 H / 1064 CE. However, more recent research mentioned that the madrasa in Naisaphur appeared earlier - around $400 \mathrm{H} / 1009$ AD - long before the Nidzamiyah madrasa. This second opinion was shared by Richard Bulliet, Naji Ma'ruf, and al-'Al. Read more; Azyumardi Azra, Islamic Education: Tradition and Modernization Towards the New Millennium (Jakarta: Logos, 1999), vii-viii. About the history of madrasa growth and development in the classical era, read more in; Ahmad Syalabi, History Islamic Education, trans. Muchtar Jahja and Sanusi Latief (Jakarta: Bulan Bintang, 1973), 109-112; George Makdisi, The Rise of Colleges: Institutions of Learning in Islam and The West (Edinburg: Edinburg University Press, 1981), In the next period the establishment of madrassas in Singapore was increasingly encouraged by religious leaders in the context of developing Islamic da'wah through education. , in 1966 in Singapore, there were 26 madrassas. But on its way, the Singapore government limited the number of madrassas to six institutions with a limited number of students. The six madrassas referred to are as follows:

The madrassas provide education in two levels, primary training, and secondary education, which includes; elementary level (ibtidaiyah) 6 years, secondary level (thanawiyah) 6 years, and pre-university level ('aliyah) 2 years. Unfortunately, to date, there is no Islamic tertiary institution in Singapore.

The six madrassas above are private institutions managed by Muslims. The majority of madrasa management funds come from Muslim contributions (both from parents' donations and the Muslim zakat-infaq-sadaqah). Also, the madrasa received regular assistance from the Singapore government and Singapore Majama Ugama Islam (MUIS). It has been explained in advance that until now, the Singapore government has limited the number of madrassas. In the view of the Singapore government, the six madrassas are enough to maintain and prepare future Muslim cadres. The rest, Muslim students, must join with other students in government-owned public schools, which numbered 173 primary schools and 156 secondary schools throughout Singapore.

In 2007 an attempt to "limit" the number of madrasas was carried out again by the government (through MUIS as an Islamic education coach) by creating a Joint Madrasah System (JMS) program which at the initial stage involved three madrasas, namely Madrasah al-Juneid, Madrasah al-'Arabiyah, and Madrasa al-Irshad. Through this program, the authority of the three madrassas in organizing education is increasingly limited. Madrasa al-Juneid and al-'Arabiyah are limited to middle-level madrassas, 
while Madrasa al-Irshad explicitly holds low-level madrassas. With this division, then since the 2009 school year, Madrasah al-Juneid and al-'Arabiyah no longer accept lowlevel prospective students and only take prospective students at the intermediate level. Likewise, with Madrasah al-Irshad, starting from the same year only taking low-level prospective students. With this policy, the number of madrasa education levels will be reduced. This has an impact on the reduced opportunity for Muslim children to enter the madrasa.

With the limited number of madrassas and prospective students accepted, many Muslim students are forced to continue to public schools. Whereas the interest of Singapore's Muslim community to put their children in madrasas is getting higher along with the increasing level of religiosity in society. This, for example, can be seen from the number of registrants to Madrasah al-Juneid, which reached 800 students in 2000 and increased to 1,000 in 2004, whereas Madrasah al-Juneid will only accept 400 students each year. The Singapore government's policy, which tends to limit the number of madrassas, is inseparable from the big agenda of the government of this country to realize national integration amid Singapore's diverse population through a nationally applicable education system.

Therefore, immediately after independence, the government closed all schools that were monopolistic, such as Chinese schools, Malay schools, and Tamil schools. The government had only left two institutions to continue to exist with tight controls, namely the madrasa, which had developed long before Singapore gained independence and the Special Assistance Plan (SAP), an educational institution intended for children who have more ability in the field of English and Mandarin language.

\section{Madrasahal-Juneidal-Islamiyah}

His full name is Madrasah al-Juneid al-Islamiyah (al-Juneid Islamic School), located on Jalan Victoria Lane 30 Singapore. This institution is the third oldest Islamic school in Singapore after Madrasah al-Sagaff and al-Arabiyah. Madrasa al-Juneid was founded by Syeid Abdur Rahman bin Umar bin Junied bin Ali al-Juneid in 1927 on the waqf land of his grandfather, Syeid Umar bin Ali al-Juneid. On the waqf land, a colonial-style two-story madrasa building was finished. The first generation of students numbered only ten boys and continues to grow as the number of Muslims grows. Over the years, Madrasah al-Juneid has attracted the attention of students not only from Singapore but also neighboring countries such as Malaysia and Brunei Darussalam.

In 1941, Madrasah al-Juneid added classrooms to meet the growing needs of registrants. At the same time, madrasa activity was disrupted due to World War II, which demanded that students and teachers return to their home regions. Madrasah alJuneid also changed its name to Darul 'Ulum al-Diniyah al-Junaidiyah. After the situation is safe, madrasa activities continue, and the original name is returned. In its 
development, the number of students increased so that the madrasa building could no longer accommodate students. Therefore, in 1991, a madrasa development committee was formed to plan a modern structure on the site of the old school. Development funds were collected from sympathetic Muslim and non-Muslim communities for the project. On August 7, 1996, the construction of a new building began. During the building process, teaching and learning activities were moved to the Language Center building on Winstedt Road, not far from the building site. In this place, they had to share with students from Madrasah al-Irshad, who were also relocated because their school building was also being restored.

On April 21, 2000, the new five-story building was officially occupied. The building that stands majestically on an area of 0.52 hectares has adequate facilities; 28 new classrooms that can accommodate up to 2000 students; two-story library room; computer room with 30 terminals; science laboratory; art studio; Sports field; theater room with 250 seats; and a multipurpose room that can accommodate 500 people.

In the narrow sense, the education curriculum is interpreted as a set of programmed subjects that must be pursued by students in a particular educational institution.25 While in a broad sense, the curriculum is defined as the overall learning experience received by students under school responsibility.

The curriculum applied at Madrasah al-Juneid experienced developments as the needs and demands of the times.27 Since this madrasa was founded in 1927 until before 1960, the curriculum was purely religiously charged (ulum al-diniyah). However, since the 1960s, this madrasa began to develop its curriculum by adding some general subjects. However, this change does not change Madrasa al-Juneid's main concern with the teaching of religion and Arabic, which is the main reason why many parents send their children to this madrasa. The curriculum development undertaken by Madrasah al-Juneid is quite slow compared to other madrassas in Singapore, such as Madrasah alMa'arif, which since the 1930s has included general lessons.

With the addition of general subjects, the curriculum composition developed by Madrasah al-Juneid to date is 70 percent of religious issues and 30 percent of general topics. The curriculum portion, which focuses more on religious material, is different from other madrassas in Singapore such as Madrasah al-Ma'arif, who choose fifty-fifty between ethical and general issues. The reason, Madrasa al-Juneid aims to prepare prospective scholars heirs to the prophet. This can be seen from the vision and mission launched by Madrasah al-Juneid as follows:

a. Madrasah Vision: Preserve generations of Islamic scholars and leaders

b. Madrasa Mission: Produce graduates who believe in Allah. in order to lead the Muslim community and serve the nation, empower students with a comprehensive and dynamic educational experience, and become a leading Islamic educational institution in developing students' potential. 
The above vision and mission can only be achieved with a neatly planned curriculum that provides more extensive portions for religious subjects. For this reason, from the low level to the pre-university level, spiritual issues in Madrasah al-Juneid have always been dominant. This is seen in the list of items for each of the following standards:

a. Issues at Primary / Low Level (6 years) or equivalent Madra-sah Ibtidaiyah, including; Tawhid, al-Qur'an, Hadith, Fiqh, Arabic, Nahwu, English, Malay, Mathematics, and Science.

b. Subjects at Secondary Level (4 years) or equivalent Madrasah Tsanawiyah, including; Tawhid, al-Qur'an, Fiqh, Insya ', Nahwu, Sharf, Tafsir, Ulumul Qur'an, Hadith, Faraidh, Rasm al-Khatt, English, Malay, Mathematics, Science, Chemistry, Biology, Physics.

c. Subjects at Pre-University Level / Pre-University Level (2 years) or equivalent to Madrasah Aliyah, including; Tauhid, al-Qur'an, Fiqh, Insya ', Nahwu, Sharf, Tafsir, Usul Fiqh, Hadith, Musthalah al-Hadis, Mantiq, Balaghah, Adab, Qawaid Fiqhiyah, English, Malay Language, Mathematics, Science, Chemistry, Chemistry Biology, Physics.

When compared with the madrasa curriculum in Indonesia, what is taking place in Madrasa al-Juneid today is more similar to the madrasa curriculum before 1975. At that time, the madrasa curriculum was dominated by religious studies and a few general lessons. In its development, especially after the government issued a Joint Ministerial Decree (Minister of Religion, Minister of Education, and Minister of Home Affairs) in 1975, the portion of the madrasa curriculum in Indonesia changed to $30 \%$ religion and 70\% general. After the government passed Law No. 2/1989 on the National Education System, the status of the madrasa shifted to become a public school characterized by Islam. With this status, general subjects in madrasas are precisely the same as in schools, thereby reducing the ration of religious matters. The level of depth of theological knowledge taught at the Madrasah al-Juneid is in line with that developed by the al-Azhar University of Egypt.30 This, among others, is in anticipation of the fact that many al-Juneid graduates continue their studies at al-Azhar University each year. With a curriculum oriented to al-Azhar, it enables its graduates not to face many obstacles when continuing their studies to the oldest Islamic university in the world.

Specifically for general subjects, the curriculum is adjusted to the Singapore Ministry of Education's minimum standards, so that al-Juneid graduates have the opportunity to continue / move to public schools / colleges by following the equality exams as required by the Singapore Ministry of Education. Interestingly, learning general material at Madrasah al-Juneid uses an integrated approach, integrated learning, with Islamic material.31 Through this approach, studies on Biology, 
Chemistry, Physics, and other general material are separate parts of Islamic studies that sourced from al-Qur'an and Sunnah.32 With this Islamic approach, and Madrasah alJuneid actually has implemented 100\% Islamic curriculum.

Efforts to integrate science or Islamization of science developed by Madrasah alJuneid are somewhat different from madrassas in Indonesia. The results of the author's research on the content of Islam in IPA33 Subjects in Madrasah Aliyah show that until now, madrasas in Indonesia have not been optimal in their efforts to integrate religious and general science. Evidently, from the results of a text study of a number of class $X$ to Biology, Chemistry, Physics textbooks to class XII at Madrasah Aliyah, almost no significant efforts were found to "connect" Islamic teachings in any discussion of science material (Biology, Chemistry, Physics) whereas the aim to Islamization is substantial to overcome the increasingly "elimination" of religious subjects in madrasas after their status changes, from religious institutions to public schools characterized by the Islamic religion.

In the history of Islam, the integration approach has actually become a tradition of Muslim scientists in classical times.35 This is marked by the emergence of Muslim philosophers and scientists who are experts in various scientific disciplines. Just to mention an example, in the field of medicine emerged; al-Razi (866-909 AD), Ibn Sina (died 926 AD), Ibn Zuhr (1091-1162 AD), Ibn Rusyd (died 1198 AD), and al-Zahrawi (died 1013 AD). In the field of philosophy emerged; al-Kindi (801-862 AD), al-Farabi (870-950 AD), al-Ghazali (1058-1111 AD), and Ibn Rusyd (died 1198 AD). In the field of exact sciences and natural sciences emerged; al-Khawarizmi (780-850 AD), al-Farghani (9th century), an-Nairazi (died 922 AD), Abu Kamil (10th century), Ibrahim Sinan (died 946 CE), al-Bir? n? (973-1051 AD), al-Khujandi (born 1000 AD), al-Khayyani (1045-1123 AD), and Nashirudin al-Th? S? (1200-1274, AD).

But the proud tradition became dim in the middle ages. The integration approach that had been built by Muslim scientists in the classical era turned into a dichotomous, religious, and general science approach. As a result, the development of general knowledge among Muslims has stalled because it is more focused on religious studies. Realizing this, a number of modern-day Muslim scientists initiated to return to the integration approach in Islamic and general studies. This idea was marked by the emergence of the term Islamization of science undertaken by Ismail Raji al-Faruqi.

The new school year at Madrasah al-Juneid begins in January, the same as public government schools. Lesson hours take place between 7:30 a.m. to 3:00 p.m., with one break, 38 and Sunday off. There are some interesting phenomena from the tradition developed by Madrasah al-Juneid, namely; the separation of male and female classrooms (except for low-level / ibtidaiyah), male students with black hats as are generally santri in Indonesia, and making Arabic a language of communication inside and outside the classroom.39 This tradition is fascinating because of Madrasas al-Juneid 
stood in the midst of Singapore's modern-secular population dominated by Western culture. In Indonesia, these traditions are only found in pesantren-based madrassas.

It seems that the application of strict Islamic traditions in Madrasah al-Juneid is related to the efforts of this institution to fortify its students from the threat of modernity, which is increasingly out of control, primarily as Singaporeans are culturally oriented toward the West. Whereas the Arabic-language tradition developed by Madrasah al-Juneid-which is difficult to find in other madrassas in Singapore -seems to be related to the tendency of these madrassas to want their graduates to continue to Islamic universities in the world. So that the provision of Arabic language skills will make it easier for graduates to be accepted at leading Islamic universities in the world, such as al-Azhar University in Cairo and universities in Saudi Arabia. and continuously improve the quality of teachers through a variety of education and training. Mainly for general subjects, they are also trained to be able to teach general material using an Islamic approach. In addition to activities that take place during school hours, Madrasah al-Juneid also develops learning activities through enrichment and remedial programs. Beyond subjects, this madrasa also seeks to develop students' talents and interests through extracurricular activities such as sports, calligraphy, astronomy, Islamic nasyid, and the Qur'anic Qur'an.

It turned out that the efforts made by Madrasah al-Juneid were not in vain. Many achievements of students / alumni of this madrasa, both in the academic field or any other field. For example, 90\% of al-Juneid graduates are accepted at a number of universities in Malaysia and the Middle East.40 These two madrasa graduates have been the best students at al-Azhar University in Egypt. Every year, the best graduates of this madrasa are also sent to Kuwait for further studies. Since 2005, al-Juneid students have always appeared as gold / silver / bronze winners in the International Mathematics Competition in the United States. In the field of sound art, the group Nasyid al-Juneid has released a number of albums since 1999 and often performs at Islamic events in Singapore.

In addition, not a few of these madrasa alumni have become religious figures and have played essential roles in the affairs of Muslims in Singapore, such as the Singapore Mufti (Syed Muhammad Isa Semait), president of the Syariah Court (Salim Jasman) and his predecessor (Haji Abu Bakar Hashim), religious leader (Ustaz Ahmad Sonhaji), and school principal (Mohamad Amin Muslim). This madrasa also gave birth to many Muslim leaders in Southeast Asian countries, especially in Malaysia and Brunei. Ninety percent of the staff of the Sarawak Islamic Council and Brunei Darussalam's Minister of Religion (Datok Muhammad Zain) is Madrasah al-Juneid alumni.

\section{d. Madrasah Challenge}

Although, in general, the presence of Madrasah al-Juneid is quite encouraging, 
this does not mean that this institution is free from problems. As an educational institution managed by a minority group in a non-Muslim developed country and mingling amid ideologically different and even conflicting cultures, Madrasa al-Juneid and all madrassas in Singapore face formidable challenges, including:

First, the demands of the world of work. The contribution of Madrasah al-Juneid in preparing Muslim cadres and leaders is not in doubt. As explained earlier, many graduates of this institution became religious leaders in several Islamic institutions in Singapore, Malaysia and Brunei Darussalam. But it must be remembered; not all alJuneid graduates will become scholars. Similar to the case of pesantren in Indonesia, all pesantren graduates can't become Kiai. Even only a small portion of them will become religious leaders. Thus, the majority of madrasa graduates will work in other sectors to support themselves.

As you know, Singapore is one of the world's business and trade centers. By implementing an open economic system, the economic actors in this country are controlled and controlled by the owners of capital and professional personnel from ethnic non-Muslim Chinese, while the Malay-Muslim ethnic group is on the periphery. During this time, they can not compete because they are weak in the field of capital and expertise. Therefore, madrassas in Singapore, in addition to equipping their students with religious knowledge, must also pay serious attention to preparing adequate provisions for their graduates to be able to compete in the world of work.

Second, the accusation of Islam as a terrorist religion. As understood, after the attack on the 11 November 2001 World Trade Center (WTC) building, which was followed by a series of radical Islamic actions in the number of parts of the world, negative views and biases towards Muslims increased, especially after the perpetrators of the fundamental movements found out. Alumni of traditional Islamic education institutions such as pesantren and madrasa. For Muslims in Singapore who are in the minority, the accusations are severe because they live in a secular state that has been known as an American-Israeli ally, which has always held a negative view of Islam. Moreover, the accusation of incrimination is often delivered vulgarly by Singapore officials. Lee Kuan Yew, former Prime Minister of Singapore, for example, some time ago, suggested that Muslims in this country develop a tolerant attitude to realize national integration during Singapore's diverse society. He views Islam in this country as a stumbling block in understanding integration. He openly expressed, "I say at this time that we can integrate all religions and races except Islam." This bias must be responded to creatively by Muslims by demonstrating - not only on the level of discourse but also in the form of daily behavior - that Islam is a peaceful, tolerant, and very non-violent religion. For madrasas, the response must also be manifested in the form of curriculum development that leads to an understanding of inclusive, tolerant, and peace-loving Islam so that graduates can live together peacefully amid 
heterogeneous Singaporeans in terms of culture, religion, race, and ethnicity.

Third, quality demands. As it is understood, besides being known as one of the world's trade centers, Singapore is also one of the countries that are very good at managing education. The National University of Singapore (NUS), for example, is the best university in Southeast Asia, ranked 3rd in Asia and 30th in the world.43 No wonder many foreigners are interested in studying in this country. The success of education in Singapore is inseparable from the full attention of the government in developing knowledge, starting from primary expertise to higher education. The government's focus can be seen from the school facilities in Singapore which are adequate. Every school in this country has free internet access. Each school also has a school website that is useful for connecting students, teachers and parents. Also, in each class, there is a Liquid Crystal Display (LCD) as a learning medium. Another facility is the availability of a transportation system that has access to all schools in Singapore, making it easier for students to go home and from school.

Another factor that makes Singapore the country with the best education system is the educator factor. To become a teacher in this country, Lion is very strict, and the prospective teachers accepted are adjusted to the number of teachers needed, so all graduate school teachers will undoubtedly get a job. After being selected, prospective teachers are given training before working so that the teachers have received adequate provisions beforehand. Besides, the salaries given to teachers in Singapore are also very high. That caused the welfare of the teachers' wellbeing to be guaranteed, so they focused on their duties as educators. For madrasas in Singapore, this is a challenge in itself considering the madrasas are outside the education system developed by the government. Madrasas, with their limited abilities, must compete with schools that receive the full attention of the government. Fourth, the challenges of the Western lifestyle. Singapore is geographically located in the Southeast Asia region, but from the cultural aspects of daily life in this lion country, it is characterized by secular, individual, materialistic, and hedonistic Western lifestyles. The development of increasingly unstoppable communication and information media has made Western lifestyles increasingly become the main choices of youth. Not a few young Muslim generations who are trapped in these lifestyles. Therefore, it is not an easy challenge for madrassas to fortify their students so that they are not eroded by Western culture. For this reason, madrasas are required to be able to develop Islamic programs that attract students' attention so that they do not look to the Western culture that is unfavorable.

\section{Conclusion}

Based on some of the explanations above, the answers to the problems in this study can be concluded as follows: First, the curriculum developed at Madrasah alJuneid was initially purely religiously charged. In its development, since the 1960s, in 
order to adjust to the needs and demands of the times, this madrasa expanded its curriculum by adding general subjects, with a composition of $70 \%$ religious studies and $30 \%$ general studies. However, because general material learning uses an integrated approach to Islamic teachings, the actual curriculum applied at Madrasah al-Juneid is 100\% Islamic curriculum.

Secondly, the madrassas in Singapore face severe challenges in the future. These challenges are the demands of the world of work, quality demands, problems of the Western lifestyle, and accusations against Islam as a terrorist religion. All these challenges must be responded to creatively by madrassas by developing quality programs so that graduates can compete with school graduates, and so that graduates can create a relaxed and tolerant Islamic life during a pluralistic Singaporean society.

\section{References}

1. Al-Faruqi, I. R. (1984). Islamization of Knowledge. Tabing: Reader.

2. Azar, A. (1999). Islamic Education: Tradition and Modernization Towards a New Millennium. Serawak: Logos.

3. Daulai, H. P. (2009). The Dynamics of Islamic Education in Southeast Asia. Serawak: Rika Cipta.

4. Fachrizal, S. (2009). Ethnic Malays; Singaporean Natives Who Are Getting More Excluded. Suara Hidayatullah.

5. Hitami, M. (2006). Islamic History of Southeast Asia. Pekanbaru: Alaf Riau.

6. Khosim, M. (2011). Islamic Content in Science Subjects in Madrasas. Petaling Jaya: PJ Library.

7. Makdisi, G. (1981). The Rise of Colleges: Institutions of Learning in Islam and The West. Edinburg: Edinburg University Press.

8. Max. Madrasas: History and Development.Kualalumpur: Logos, 1999.

9. Miel, A. (1946). Changing the Curriculum a School Process. New York; Apletion Century Company.

10. Mokhtar, I. A. (2010). Madrasahs in Singapore: Bridging Between Their Roles, Relevance and Resources. Journal of Muslim Minority Affairs.

11. Nasution, A. (1975). Renewal in Islam: A History of Thought and Movement. Jakarta: Star Moon.

12. The Singapore Islamic Education System a Conceptual Framework developed by the Youth Education Strategic Unit of the Islamic Religious Council of Singapore (MUIS), 27 April 2007 edition.

13. Education Statistics Directorate of Islamic Education Ministry of Religion, 2009-2010.

14. Steenbrink, K. A. (1994). Islamic Boarding School: Islamic Education in the Modern Period. Kualalumpur 
15. Syalabi, A. (1973). History of Islamic Education, trans. Muchtar Jahja and Sanusi Latief. Jakarta: Crescent Star.

16. Turner, B. S. (2010). Kamaludin Mohamed Nasir and Alexux A. Pereira. Muslims in Singapore; Piety, Politics and Policies. London: Routledge Taylor \& Francis Group. 17. Webster's. (1953). New International Dictionary. New York: GC Merriam Company. 18. Jonah, M. (1996). History of Islamic Education in Indonesia. Jakarta: Hidakarya Agung. 